\title{
THE EFFECT OF ADDITIVES AND REDUCTORS IN SELECTIVE REDUCTION PROCESS OF LATERITE NICKEL ORE
}

\author{
F. Nurjaman ${ }^{1}$, A. Sa'adah ${ }^{2}$, A. Shofi ${ }^{1}$, W. Apriyana ${ }^{3}$ and B. Suharno ${ }^{2}$ \\ ${ }^{1}$ Research Unit for Mineral Technology - LIPI \\ Jl. Ir. Sutami, Km 15 Tanjung Bintang, Serdang, Lampung 35361 \\ ${ }^{2}$ Departement of Metallurgical and Materials Engineering, University of Indonesia \\ Kampus Baru UI, Depok 16424 \\ ${ }^{3}$ Research Unit for Natural Technology - LIPI \\ Daerah Istimewa Yogyakarta 55861 \\ E-mail:fajar.nurjaman@lipi.go.id
}

Received: 11 August $2018 \quad$ Revised: 28 August $2018 \quad$ Accepted: 28 September 2018

\begin{abstract}
THE EFFECT OF ADDITIVES AND REDUCTORS IN SELECTIVE REDUCTION PROCESS OF LATERITE NICKEL ORE. Selective reduction of laterite nickel ore followed by magnetic separation was carried out to produce ferronickel products. The effect of adding additives and reductor types in the selective reduction process was studied in this study. Reductors used were anthracite coal and palm shell charcoal with variations of 5 to $15 \%$ by weight, while the additive used was sodium sulfate $\left(\mathrm{Na}_{2} \mathrm{SO}_{4}\right)$. The reduction process was carried out at temperatures of $950{ }^{\circ} \mathrm{C}, 1050^{\circ} \mathrm{C}$ and $1150^{\circ} \mathrm{C}$ for 60 minutes. The addition of $10 \%$ sodium sulfate additives by weight in the reduction process of laterite nickel ore produced higher concentrations of nickel as $6.09 \%$, compared to no additives, i.e. $2.45 \%$. The addition of reductors in the selective reduction process of laterite nickel ore shows that the higher the amount of reductors causes a decrease in the concentrate level of nickel. Furhtermore, the type of reductors used shows that the concentrate from the reduction result using anthracite coal reductor produces higher level of nickel and lower level of iron compared to the use of palm shell charcoal reductor.
\end{abstract}

Keywords: Laterite nickel ore, Selective reduction, Ferronickel, Sodium sulfate, Anthracite coal, Palm shell charcoal

\begin{abstract}
ABSTRAK
PENGARUH ADITIF DAN REDUKTOR PADA PROSES REDUKSI SELEKTIF BIJIH NIKEL

LATERIT. Reduksi selektif bijih nikel laterit diikuti dengan pemisahan magnetik dilakukan untuk menghasilkan produk ferronikel. Pengaruh penambahan aditif dan jenis reduktor dalam proses reduksi selektif telah dipelajari dalam penelitian ini. Reduktor yang digunakan, yaitu batubara antrasit dan arang cangkang sawit dengan variasi 5 hingga $15 \%$ berat, sedangkan aditif yang digunakan adalah sodium sulfat $\left(\mathrm{Na}_{2} \mathrm{SO}_{4}\right)$. Proses reduksi dilakukan pada temperatur $950^{\circ} \mathrm{C}, 1050^{\circ} \mathrm{C}$ dan $1150^{\circ} \mathrm{C}$ selama 60 menit. Penambahan aditif sodium sulfat sebanyak $10 \%$ berat dalam proses reduksi bijih nikel laterit menghasilkan kadar nikel dalam konsentrat yang lebih tinggi yaitu $6,09 \%$, jika dibandingkan tanpa aditif, yaitu $2,45 \%$. Pada penambahan reduktor dalam proses reduksi selektif bijih nikel laterit, menunjukkan bahwa semakin tinggi jumlah reduktor menyebabkan penurunan kadar nikel dalam konsentrat. Disamping itu dari jenis reduktor yang digunakan menunjukkan bahwa konsentrat hasil reduksi menggunakan reduktor batubara antrasit menghasilkan kadar nikel yang lebih tinggi dan besi yang lebih rendah jika dibandingkan dengan penggunaan reduktor arang cangkang sawit.
\end{abstract}

Kata kunci: Bijih nikel laterit, Reduksi selektif, Ferronikel, Sodium sulfat, Batubara antrasit, Arang cangkang sawit 


\section{INTRODUCTION}

Nearly $81 \%$, nickel is used as one of the alloying elements in the manufacture of stainless steel and alloy steel [1]. In Indonesia, a large scale of nickel laterite deposits is found in Sulawesi islands. [2]. Laterite ores account for $72 \%$ of global nickel sources, but only $42 \%$ are used for primary nickel metal production. In contrast, sulfide ore accounts for $58 \%$ of nickel production [3]. This is because the technological challenge in processing laterite nickel ore is more difficult compared to nickel sulfide ore [1]. To meet the high demand for nickel in the future, laterite nickel can be used as an alternative raw material, due to the depletion of nickel sulfide ore reserves [4].

One method for processing laterite nickel ore into ferronickel is a reduction process at a temperature of $1000-1200^{\circ} \mathrm{C}$, followed by a magnetic separation method, otherwise known as the selective reduction method [5]. Reduction of laterite nickel ore is carried out using carbon-based reductors, which will produce $\mathrm{CO}$ gas which will reduce metal oxide compounds, as shown in equation (1).

$$
\begin{aligned}
& \mathrm{C}+\mathrm{CO}_{2} \rightarrow 2 \mathrm{CO} \\
& 2(\mathrm{Fe}, \mathrm{Ni}) \mathrm{O} . \mathrm{OH} \rightarrow(\mathrm{Fe}, \mathrm{Ni})_{2} \mathrm{O}_{3}+\mathrm{H}_{2} \mathrm{O} \\
& 6(\mathrm{Fe}, \mathrm{Ni}) \mathrm{O} . \mathrm{OH} \rightarrow 2\left(\mathrm{Fe}, \mathrm{Ni}_{3} \mathrm{O}_{4}+3 \mathrm{H}_{2} \mathrm{O}+0,5 \mathrm{O}_{2} \ldots \ldots . . . . . . .\right. \\
& \mathrm{NiFe}_{2} \mathrm{O}_{4}+\mathrm{CO} \rightarrow \mathrm{Ni}+\mathrm{Fe}_{2} \mathrm{O}_{3}+\mathrm{CO}_{2} \\
& 3 \mathrm{Fe}_{2} \mathrm{O}_{3}+\mathrm{CO} \rightarrow 2 \mathrm{Fe}_{3} \mathrm{O}_{4}+\mathrm{CO}_{2} \\
& \mathrm{Fe}_{3} \mathrm{O}_{4}+\mathrm{CO} \rightarrow 3 \mathrm{FeO}+\mathrm{CO}_{2} \\
& \mathrm{FeO}+\mathrm{CO} \rightarrow \mathrm{Fe}+\mathrm{CO}_{2}
\end{aligned}
$$

Nickel in the limonite ore is substituted in the goethite crystal structure which at $300{ }^{\circ} \mathrm{C}$ goethite dehydroxylation occurs by reaction in equation (2) [6]. After dehydroxylation, nickel is formed in the hematite spinel structure. Nickel will join into the magnetite spinel phase under the condition of reduction through the reaction in equation (3) which is then reduced, through the reaction in equation (4) to be $\mathrm{Ni}$ metal and iron hematite compound [7]. The process of reducing iron oxide to iron metal is shown in the reaction in equation (5-7).
Addition of additives in the selective reduction process is carried out to increase the content and yield of $\mathrm{Ni}$ in nickel ore concentrates. Additives containing sulphur are generally used to increase the levels and yield of nickel in concentrates, including elemental sulphur [6,8], sodium sulfate [9-11], calcium sulfate $[12,13]$, and pyrite [14]. Sodium sulfate provides a more effective reduction result compared to other additives. Jiang et al. [15] conducted a selective reduction process of laterite nickel ore as $1.49 \% \mathrm{Ni}$ by adding $10 \% \mathrm{Na}_{2} \mathrm{SO}_{4}$ additive and $2 \%$ reductor of bituminous coal at a temperature of $1200{ }^{\circ} \mathrm{C}$ for 50 minutes, and obtained ferronickel concentration of $9.87 \% \mathrm{Ni}$ and nickel yield as $90.9 \%$. Li et al. [16] also conducted a selective reduction process of $1.9 \% \mathrm{Ni}$ laterite nickel by adding an additive of $20 \% \mathrm{Na}_{2} \mathrm{SO}_{4}$ and lignite coal reductor at a temperature of $800-1200{ }^{\circ} \mathrm{C}$ for 60 minutes, and obtained optimum ferronickel concentrate with a content of $9.48 \% \mathrm{Ni}$ and a nickel yield of $83.02 \%$ at a reduction temperature of $1100^{\circ} \mathrm{C}$.

The use of reductors in the reduction selective process of laterite nickel ore aims to reduce the metal oxide compounds found in laterite nickel ore. Table 1 shows several types of reductors and additives used in the reduction process of laterite nickel ore. Anthracite coal has a higher caloric value than bituminous and lignite, so its use in the industrial world as fuel is quite extensive that the selling value of low-sulphur anthracite coal is much higher than both of them. A problem arises in anthracite coal with high sulphur content, where its use as fuel in electric power plants can trigger corrosion of boiler pipe metals, so the use of this type of coal is very little.

In this study, $10 \%$ sodium sulfate additives were used to reduce nickel ore $(1.4 \mathrm{Ni})$ with high $\mathrm{Fe}$ and $\mathrm{Si}$ contents (50.5 Fe and 16.5 Si, respectively). The effect of using sodium sulfate additives on the reduction process nickel ore was studied in this research. Anthracite coal with high sulphur content was used as a reductor in this study. In addition, as shown in Table 1, the use of biomass as material reductor is also not widely

\begin{tabular}{|c|c|c|c|c|c|c|c|}
\hline \multirow{2}{*}{$\begin{array}{l}\text { Laterite Nickel } \\
\text { Ore Type }\end{array}$} & \multicolumn{4}{|c|}{ Ore composition (\%) } & \multirow{2}{*}{ Reductor } & \multirow{2}{*}{ Aditive } & \multirow{2}{*}{ Literature } \\
\hline & $\mathrm{Ni}$ & $\mathrm{Fe}$ & $\mathrm{MgO}$ & $\mathrm{SiO}_{2}$ & & & \\
\hline Limonite & 1.33 & 56 & 0.83 & 2.98 & Bituminus & Sulfur and pirit & Elliot et al. 2017 [4] \\
\hline Limonite & 1.11 & 48.68 & 3.04 & 14.84 & Bituminus & $\mathrm{CaSO}_{4}$ & Mayangsari dkk 2016 [17] \\
\hline Saprolite & 1.49 & 34.69 & 12.28 & 20.05 & Bituminus & $\mathrm{Na}_{2} \mathrm{SO}_{4}$ & Jiang et al. $2013[15]$ \\
\hline Saprolite & 1.91 & 22.1 & 13.4 & 26.49 & Lignit & $\mathrm{Na}_{2} \mathrm{SO}_{4}$ & Li et al. 2012 [16] \\
\hline Limonite & 0.97 & 40.90 & 4.65 & 12.55 & Bituminous, & $\mathrm{CaSO}_{4}$ & Zhu et al., 2012 [12] \\
\hline Saprolite & 1.42 & 23.16 & 17.65 & 27.74 & graphite & & \\
\hline Limonite & 1.8 & 16.54 & 6.81 & 20.97 & LPG & - & Itao and Anacleto, 2011 \\
\hline Saprolite & 1.38 & 25.3 & 14.99 & 19.07 & $\mathrm{H}_{2}: 70 \%, \mathrm{~N}_{2}: 30 \%$ & $\mathrm{Na}_{2} \mathrm{SO}_{4}$ & Lu et al. 2013 [19] \\
\hline
\end{tabular}
used. Therefore, this research also used palm shell charcoal reducing agent (with $0 \%$ sulphur content) in the reduction process of nickel ore. The effect of the sulphur content in reductors was studied in this research.

Table 1. Selective reduction of Laterite Nickel Ore as Additive and reduction 


\section{EXPERIMEN METHOD}

\section{Materials}

Laterite nickel ore in this study is derived from Southeast Sulawesi, Indonesia. The chemical composition of laterite ore is based on an analysis using XRF as shown in Table 2. Anthracite coal and palm shell charcoal are used as reductors. The proximate analysis of reductors is shown in Table 3. Sodium sulphate was used as an additive in the selective reduction process of laterite nickel ore in this study.

Table 2. Chemical composition of Nickel ore

\begin{tabular}{cccccccccc}
\hline Element & $\mathrm{Ni}$ & $\mathrm{Fe}$ & $\mathrm{Si}$ & $\mathrm{Mg}$ & $\mathrm{Al}$ & $\mathrm{Ca}$ & $\mathrm{Cr}$ & $\mathrm{Mn}$ & $\mathrm{Co}$ \\
\hline \% Weight & 1.4 & 50.5 & 16.5 & 1.81 & 4.86 & 0.177 & 2.68 & 0.847 & 0.0662
\end{tabular}

Table 3. Proximate analysis redactor (\% weight)

\begin{tabular}{ccccc}
\hline Reductor & Moisture & \begin{tabular}{c} 
Component (\%) \\
\cline { 3 - 4 }
\end{tabular} & $\begin{array}{c}\text { Ash } \\
\text { content }\end{array}$ & $\begin{array}{c}\text { Fixed } \\
\text { carbon }\end{array}$ \\
\hline $\begin{array}{c}\text { Antrasit Coal } \\
\text { Palm Shell } \\
\text { Charcoal }\end{array}$ & 3.14 & 18.25 & 18.25 & 60.35 \\
\hline
\end{tabular}

\section{Procedure}

Nickel ore and reductors are crushed to a size of less than $149 \mu \mathrm{m}(-100 \mathrm{mesh})$. As much as 100 grams of laterite nickel ore, $5 \%$ of reductors weight and $10 \%$ of sodium sulphate weight are mixed and made into pellets $10-15 \mathrm{~mm}$ in diameter. The pellets were dried in an oven at a temperature of $120{ }^{\circ} \mathrm{C}$ for 4 hours to remove the water content, then put into graphite crucible for further reduction process using muffle furnace at temperatures of $950{ }^{\circ} \mathrm{C}, 1050{ }^{\circ} \mathrm{C}$ and $1150{ }^{\circ} \mathrm{C}$ for 60 minutes. After the reduction process, the pellets were removed from the muffle furnace and cooled quickly using water.

The magnetite separation process was carried out at the next stage to separate the concentrate and tailings. Concentrates that are rich in iron and nickel alloy metals are magnetic while tailings containing impurities (non metallic oxides) are non magnetic. The reduced nickel ore was crushed to a size of $74 \mu \mathrm{m}$ before the magnetic separation process is carried out in a wet manner using magnets of 500 Gauss.

Phase transformations or changes in compounds in laterite nickel ore during the reduction process were analyzed using XRD. XRF analysis was conducted to determine the levels of nickel and iron in ferronickel concentrates, while SEM-EDS was used for ferronickel particle morphology. The recovery of nickel and iron is calculated based on equations (8) and (9).

$$
\begin{aligned}
N i \text { Acquisition } & =\frac{\% \text { Ni concentrate }}{\% \text { Laterite Nickel Ore }} \\
N i \text { Acquisition } & =\frac{\% \text { Fe concentrate }}{\% \text { Fe Laterite Nickel Ore }}
\end{aligned}
$$

\section{RESULTS AND DISCUSSION}

\section{The Effect of Additives Addition}

Figure 1 shows the levels and yields of $\mathrm{Ni}$ and $\mathrm{Fe}$ from the concentrations of magnetic separation results with the addition of $10 \% \mathrm{Na}_{2} \mathrm{SO}_{4}$ with and without additives at a reduction temperature of $950{ }^{\circ} \mathrm{C}, 1050{ }^{\circ} \mathrm{C}$ and $1150{ }^{\circ} \mathrm{C}$ for 60 minutes with anthracite coal reductor. The level and yield of $\mathrm{Ni}$ and $\mathrm{Fe}$ in the concentrate without additive (Figure 1(a)) increase along with the increasing reduction temperature from $950{ }^{\circ} \mathrm{C}$ to $1150{ }^{\circ} \mathrm{C}$. This is also indicated by the results of XRD analysis (Figure 2), where the intensity of FeNi peak increases along with the increasing reduction temperature. This is also indicated by the decreasing intensity of $\mathrm{FeO}$, which shows that the rate of reduction of iron oxide compounds into Fe metal increases with the increasing of reduction temperature. Furthermore, Fe metal will associate with Ni metal to form ferronickel (FeNi). However, the optimum levels of $\mathrm{Ni}$ and $\mathrm{Fe}$ are only $2.45 \%$ and $57.03 \%$, respectively, which are obtained at a reduction temperature of $1150^{\circ} \mathrm{C}$.
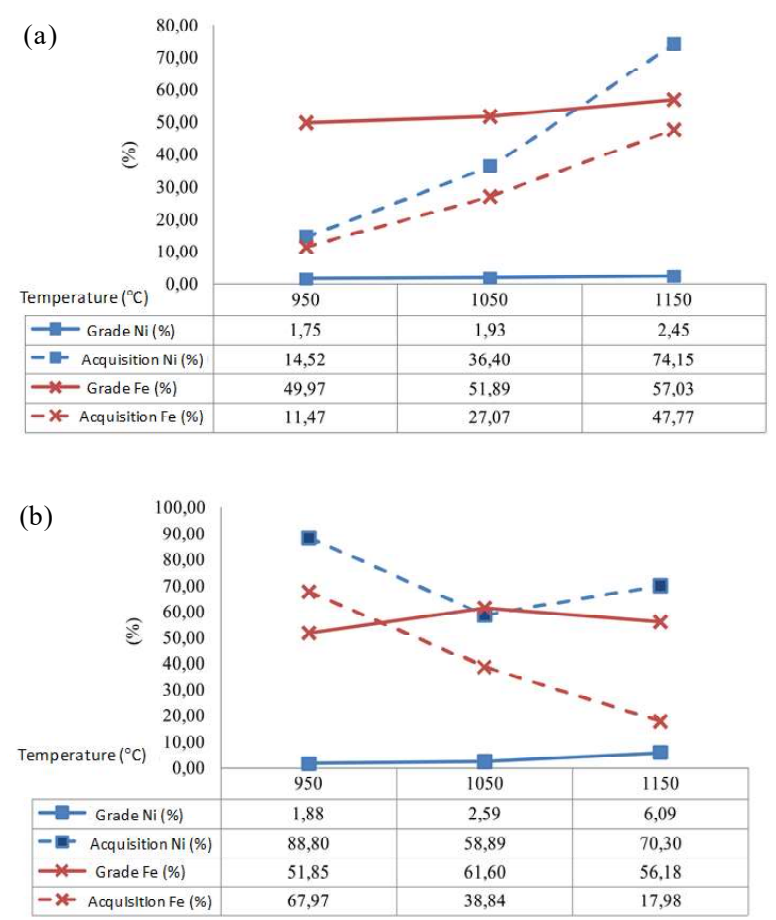

Figure 1. The effect of additive addition on the levels and recovery of $\mathrm{Ni}$ and $\mathrm{Fe}$ in concentrates at temperatures of 950 to $1150{ }^{\circ} \mathrm{C}$ for 60 minutes: (a). without $\mathrm{Na}_{2} \mathrm{SO}_{4}$, (b). with $\mathrm{Na}_{2} \mathrm{SO}_{4} \mathrm{C}$

With the presence of sulphur-based additives, troilite $(\mathrm{FeS})$ compounds are formed [10], as shown by the results of XRD analysis (Figure 3), where FeS compounds are present at reduction temperatures of $950{ }^{\circ} \mathrm{C}, 1050{ }^{\circ} \mathrm{C}$ and $1150^{\circ} \mathrm{C}$. the reduced $\mathrm{Na}_{2} \mathrm{SO}_{4}$ produces $\mathrm{Na}_{2} \mathrm{~S}$. Then $\mathrm{Na}_{2} \mathrm{~S}$ reacts with $\mathrm{FeO}$ to form FeS with a reaction in equation (6-7). 


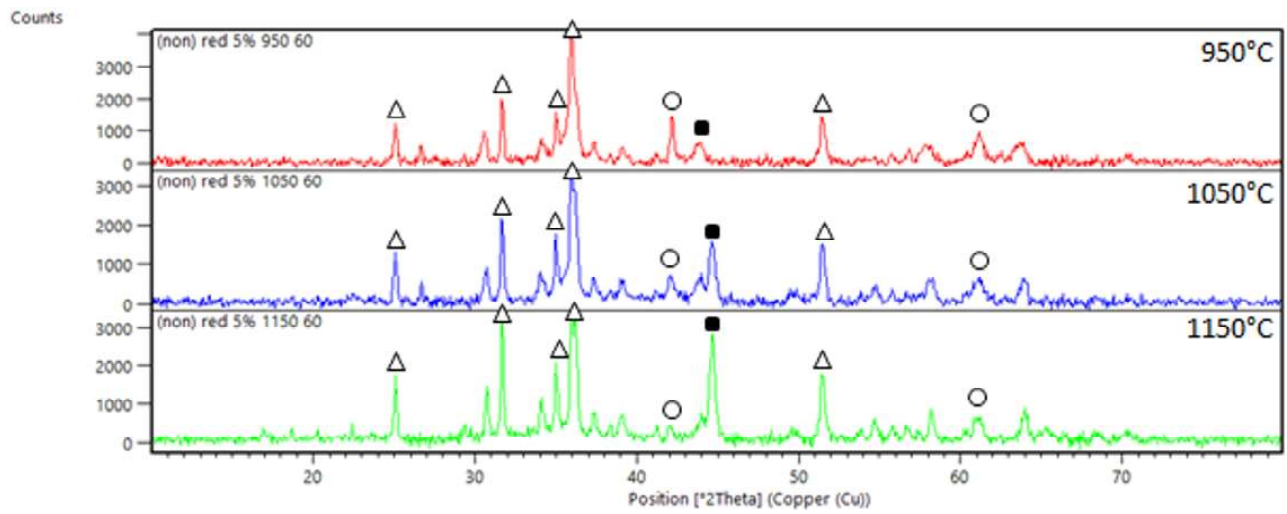

Figure 2. The results of XRD analysis for the reduction of nickel lat-erite ore without additives for 60 minutes with the addition of $5 \%$ anthracite coal reductor $\left(\Delta=(\mathrm{Fe}, \mathrm{Mg})_{2} \mathrm{SiO}_{4}, \mathbf{m}=\mathrm{FeNi}, \circ=\mathrm{FeO}\right)$.

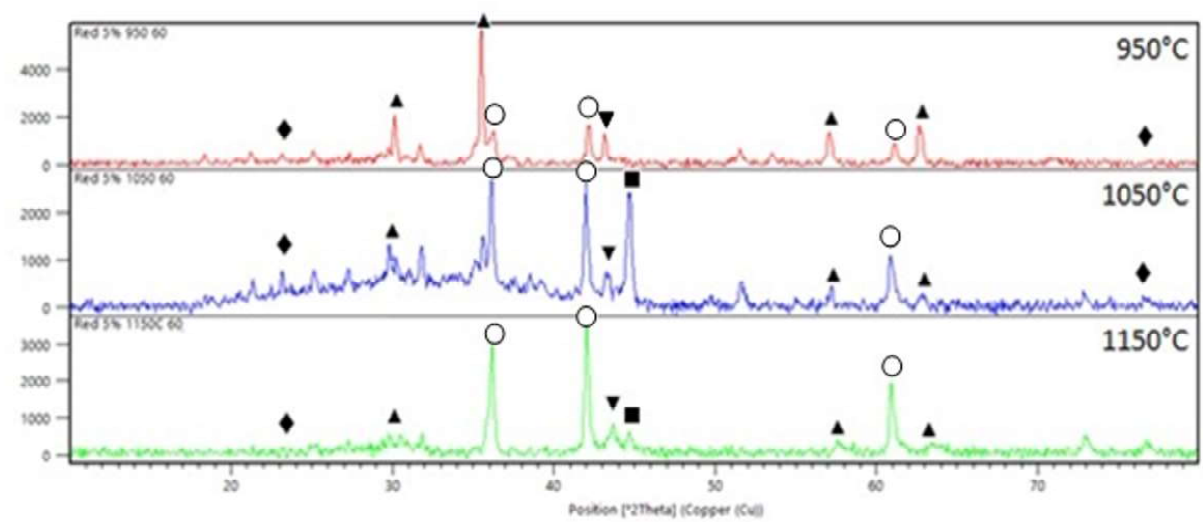

Figure 3. The results of XRD analysis for the reduction of nickel laterite ore with $10 \% \mathrm{Na}_{2} \mathrm{SO}_{4}$ additive for 60 minutes with the addition of $5 \%$ anthracite coal reductor $\left(\boldsymbol{\nabla}=\mathrm{FeS}, \boldsymbol{\Lambda}=\mathrm{Fe}_{2} \mathrm{SiO}_{4}\right.$, - $=\mathrm{FeNi}, \circ=\mathrm{FeO}, "=\mathrm{SiO}_{2}$ ).

$1 / 4 \mathrm{Na}_{2} \mathrm{SO}_{4}+\mathrm{CO} \rightarrow 1 / 4 \mathrm{Na}_{2} \mathrm{~S}+\mathrm{CO}_{2}$

$\mathrm{Na}_{2} \mathrm{~S}+\mathrm{FeO}+2 \mathrm{SiO}_{2} \rightarrow \mathrm{Na}_{2} \mathrm{Si}_{2} \mathrm{O}_{5}+\mathrm{FeS}$

When laterite ore was reduced at temperatures of $950{ }^{\circ} \mathrm{C}, 1150{ }^{\circ} \mathrm{C}$ and $1150{ }^{\circ} \mathrm{C}$ for 60 minutes with the addition of $10 \% \mathrm{Na}_{2} \mathrm{SO}_{4}$ (Figure $2 \mathrm{~b}$ ), $\mathrm{Ni}$ and $\mathrm{Fe}$ increased respectively from $1.4 \%$ and $50.85 \%$ (in nickel ore) to $6.09 \%$ and $56.18 \%$ (in concentrate). From these results, it can be seen that the ore which is reduced by the addition of additives produces concentrates with higher nickel and lower iron compared to without additives.

The presence of non magnetic FeS phase can reduce the yield of $\mathrm{Fe}$ in concentrates, so that the $\mathrm{Ni}$ content will increase. In addition, with the higher reduction temperature, FeS compounds can also inhibit the reduction process of wustite $(\mathrm{FeO})$ compounds into Fe metal. This is indicated by the increasing intensity of $\mathrm{FeO}$ compounds, as shown in Figure 3, along with the increase in reduction temperature. $\mathrm{FeO}$ is paramagnetic, so it will be grouped into tailings with $\mathrm{FeS}$ after the magnetic separation process is carried out. The low peak of FeNi in Figure 3 shows that FeNi concentrates are rich in nickel content (with less iron content).
From the results of microstructure analysis, as shown in Figures 4 and 5, bright grains show ferronickel formed from the reduction of nickel ore, while dark grains are impurities with the dominant elements $\mathrm{Si}$ and $\mathrm{O}$ (quartz/ $\mathrm{SiO}_{2}$ ). From the figures, changes in grain distribution and size formed when the ore is reduced with and without additives at temperatures of $950{ }^{\circ} \mathrm{C}$ to $1150^{\circ} \mathrm{C}$ are visible. The grain size of ferronickel in both types of concentrates increases with increasing
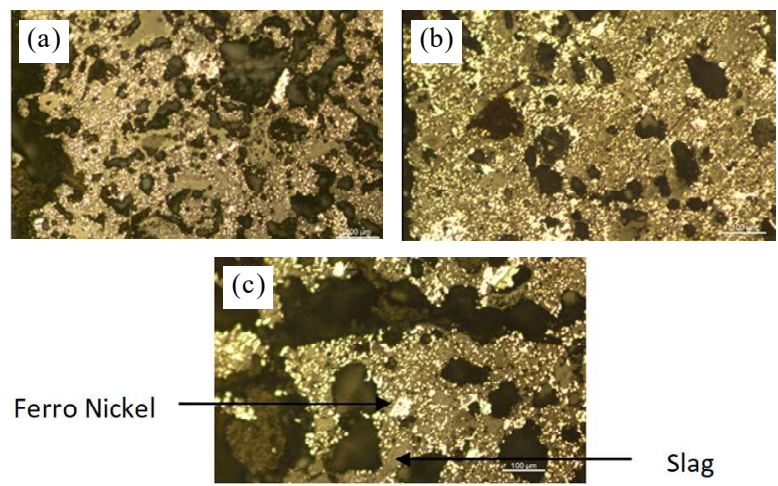

Figure 4. Pellet microstructure which was reduced with and without $\mathrm{Na}_{2} \mathrm{SO}_{4}$ at different temperatures for 60 minutes: (a). $950{ }^{\circ} \mathrm{C}$, (b). $1050^{\circ} \mathrm{C}$, and (c). $1150{ }^{\circ} \mathrm{C}$. 
temperature, but the ferronickel content in the concentrate with the addition of $10 \%$ sodium sulfate (Figure 5) has a larger size than the concentrate without additive (Figure 4). This is due to the low eutectic temperature of the $\mathrm{FeFeS}$ phase formed by sodium sulphate additive, which is $985^{\circ} \mathrm{C}$, so that the liquid $\mathrm{FeS}$ phase is formed at a reduction temperature of $1050^{\circ} \mathrm{C}$. In the liquid phase, the metal transfer movement becomes easier so that the ferronickel undergoes agglomeration. The diffusion rate of metal elements will be higher as the temperature increases, so the higher reduction temperature can accelerate the growth of ferro nickel grain so that the grain size of ferronickel becomes larger [10].

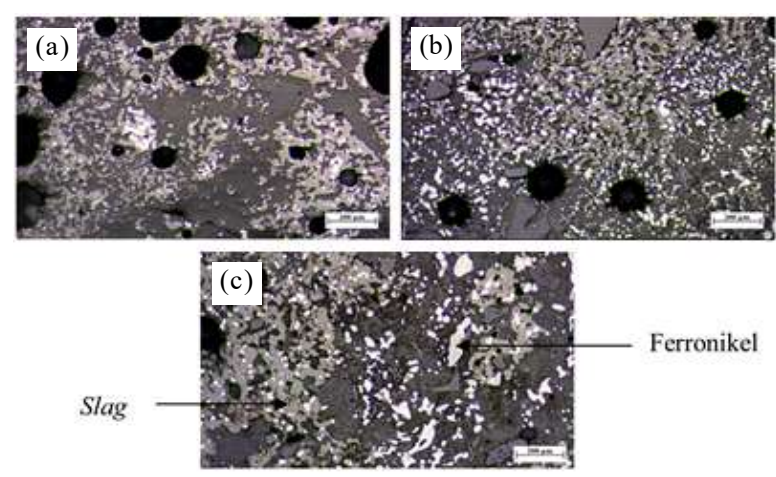

Figure 5. Pellet Microstructure which wash reduced by $\mathrm{Na}_{2} \mathrm{SO}_{4}$ with different temperature for 60 minutes: (a). $950{ }^{\circ} \mathrm{C}$, (b). $1050{ }^{\circ} \mathrm{C}$, dan (c). $1150{ }^{\circ} \mathrm{C}$.

\section{The Effect of Amount and Types of Reductors}

The greater the amount of reductors used, the higher the concentration produced [20]. Figure 6 shows the level and yield of $\mathrm{Ni}$ and Fe concentrates from the

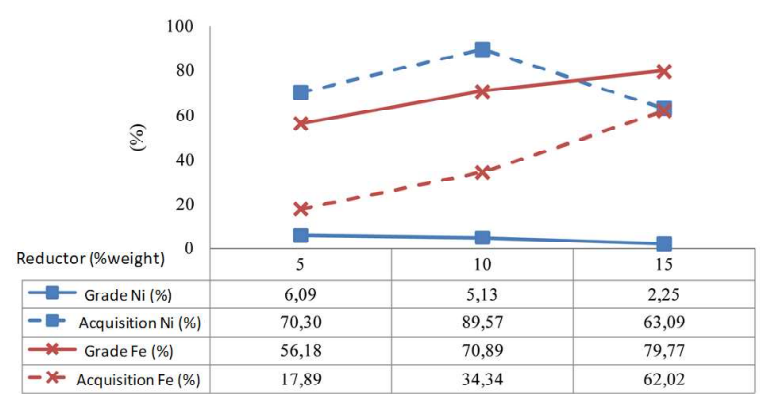

Figure 6. The effect of the number of reductors on concentrates with additives of $10 \% \quad \mathrm{Na}_{2} \mathrm{SO}_{4}$ at a temperature of $1150{ }^{\circ} \mathrm{C}$ and for 60 minutes against: (a). Ni and Fe levels and (b). Ni and Fe recovery.

reduction of laterite nickel ore using anthracite coal reductors. Based on the graph, the iron content increases along with the increase in the amount of reductors, from $56.18 \%$ to $79.77 \%$. Likewise on the yield of iron metal. The more reductors are added, the $\mathrm{CO}$ gas produced during the reduction process will also increase and cause the reduction process of iron oxide into metal become more optimal. However, this phenomenon is not desirable in a selective reduction process, where the expected conditions are high levels and yields of nickel by obtaining low iron levels and yields on the concentrate. From Figure 6, nickel content tends to decrease from $6.1 \%$ in the addition of $5 \%$ reductor to $2.25 \%$ in the addition of $15 \%$ reductor. The same thing happened to the yield of nickel metal, although it had increased at the addition of $10 \%$ reductor. The higher the addition of reductor, the lower the level and yield of nickel [12]. The increase in the level of reductor to reach the optimal amount of carbon can contribute to the reduction of iron and nickel so that the metal yield increases, but excessive carbon can resist the increase in nickel levels

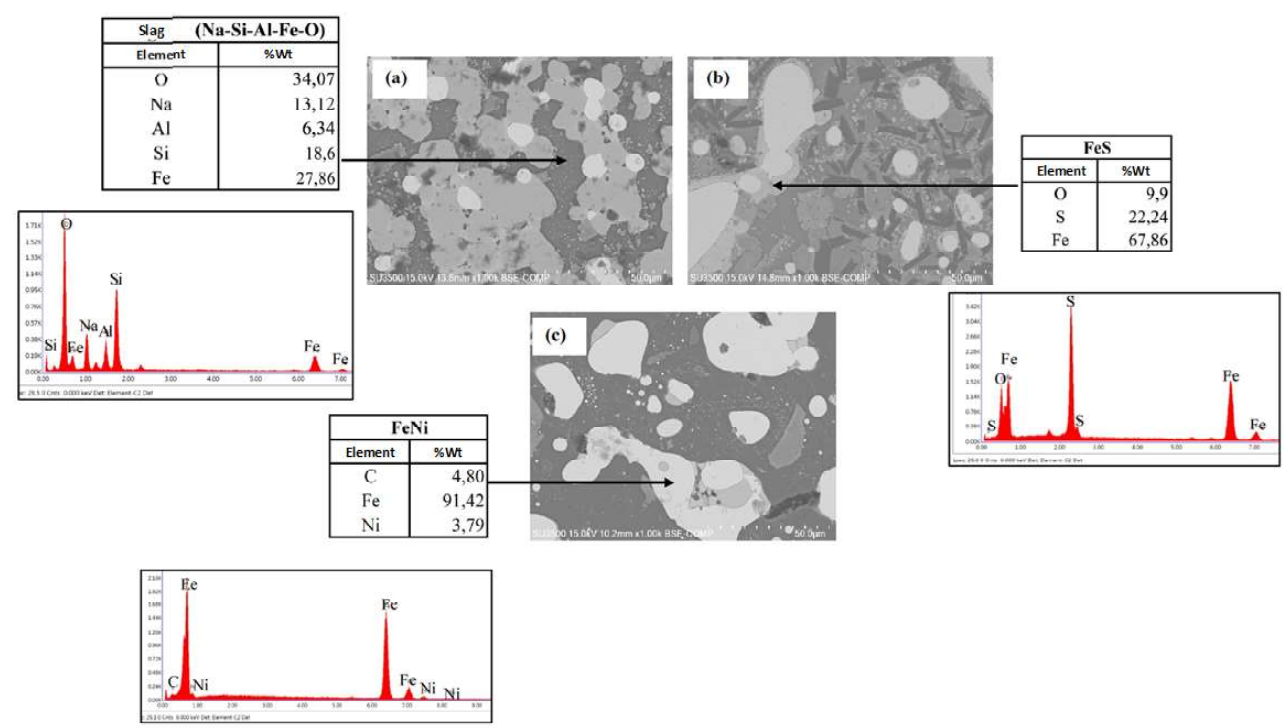

Figure 7. Microstructure (SEM-EDAX photo magnification of $500 \mathrm{BSE}$ ) of pellets which has been reduced at a temperature of $1150{ }^{\circ} \mathrm{C}$ for 60 minutes with $10 \% \mathrm{Na}_{2} \mathrm{SO}_{4}$ with anthracite coal reductors: (a). 5 , (b) 10 , and (c). $15 \%$ by weight. 
and also lead to decreased nickel yield [21]. Nickel levels decrease due to the formation and increase in the amount of iron [22]. The addition of carbon (derived from reducing reductors) which is greater than that needed for the purpose of obtaining high nickel yields can actually reduce nickel levels due to an increase in reduction of iron oxide to metallic iron [3].

From the results of microstructure analysis (Figure 7), bright grains are from metal (ferronickel) particles formed, while dark grains are identified as impurities. From Figure 7, it appears that there is a change in the grain size formed due to the reduction process of laterite nickel ore with the addition of anthracite coal reductor as $5-15 \%$. In addition to the amount of reductor $5 \%$ by weight, the ferronickel grain is not too much. The more additions to the number of reductor, the more ferronickel grains get larger and bigger because the more iron oxide is reduced to iron metal and into ferronickel, which is not desirable.

Figure 8 shows the effect of using the types of palm shell charcoal and antithetite coal reductors on the levels and yields of iron and nickel at various reduction temperatures. From the experimental results it appears that, the higher the reduction temperature, the higher the level of nickel in the concentrate. The highest nickel level in both concentrates was obtained at $1150{ }^{\circ} \mathrm{C}$ reduction temperature. The ore reduced by anthracite coal has a higher nickel level, which is $6.1 \% \mathrm{Ni}$, compared to palm shell charcoal, which is $4.6 \% \mathrm{Ni}$. For iron level,

(a)
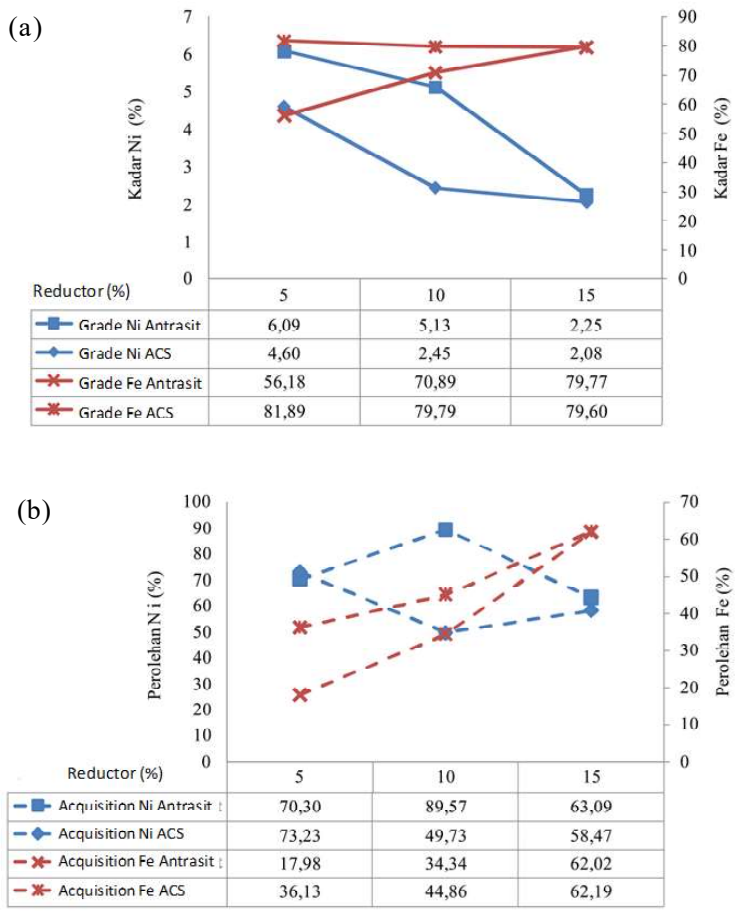

Figure 8. (a). The effect of the types of reductors on the levels and recovery of $\mathrm{Ni}$ and $\mathrm{Fe}$ in concentrates of $10 \% \mathrm{Na}_{2} \mathrm{SO}_{4}$ at temperatures of $950{ }^{\circ} \mathrm{C}, 1050{ }^{\circ} \mathrm{C}$ and $1150{ }^{\circ} \mathrm{C}$ for 60 minutes with reductors: (a). Anthracite, (b). Palm shell charcoal the nickel ore reduced by anthracite produces lower levels of iron, which is $61.6 \%$ compared to palm shell charcoal, which is $81.89 \%$.

The same thing happened to the yields of nickel and iron. At a temperature of $1150^{\circ} \mathrm{C}$, the yield of nickel from both types of concentrate is not much different. As for iron yield, concentrates with anthracite coal reductor produce lower iron yield compared to concentrates with palm shell charcoal reductor.

From the results of these experiments, it was found that laterite nickel ore which was reduced by anthracite coal produced better concentrations, which concentrates with high nickel content and low iron content were obtained. This is due to the higher sulphur content found in anthracite coal reductor compared to palm shell charcoal, as shown in Table 4.

Table 4. The analysis results of anthracite coal and palm shell char-coal

\begin{tabular}{lcc}
\hline \multirow{2}{*}{ Reductor } & \multicolumn{2}{c}{ Component } \\
\cline { 2 - 3 } & Sulphur $(\%)$ & Calory $(\mathrm{Cal} / \mathrm{g})$ \\
\hline Anthracite Coal & 3.14 & 18.25 \\
Palm Shell Charcoal & 0.43 & 22.57 \\
\hline
\end{tabular}

The presence of sulphur, both from additives and reductors will increase the rate of kinetic reduction and reduce iron metallization and facilitate the formation of FeS which can increase nickel selectivity so that nickel yield increases [12]. Therefore, the more sulphur content, the more $\mathrm{FeS}$ is formed and FeS can increase the nickel level in concentrate by suppressing the formation of iron into metal which causes the iron to enter the tailings so that the iron yield in concentrate becomes low [16].

\section{CONCLUSION}

Addition of $\mathrm{Na}_{2} \mathrm{SO}_{4}$ additive to the selective reduction of low level laterite nickel ore with a content of $1.4 \% \mathrm{Ni}$ can increase nickel content in concentration up to $6.09 \% \mathrm{Ni}$ at a reduction temperature of $1150^{\circ} \mathrm{C}$ for 60 minutes. In addition, the presence of $\mathrm{Na}_{2} \mathrm{SO}_{4}$ contributes to an increase in the particle size of ferronickel, where the size becomes larger and thus has a positive impact on the magnetic separation process which results in increased nickel metal concentrations. While the addition of reductors results in decreased levels of nickel in concentrates due to the optimal reduction of iron oxide to metal. The highest nickel level is obtained at the amount of $5 \%$ reductor. Ore, which is reduced by anthracite coal reductor, produces higher concentrations of nickel level and lower iron compared to ore reduced by palm shell charcoal. This is due to higher sulphur content in anthracite coal. Sulphur can react with iron and form FeS which can reduce iron metallization to increase the nickel level in concentrate. 


\section{ACKNOWLEDGEMENT}

The author would like to thank Kemenristekdikti for funding this research through Insinas Budget Year 2018 program No. 06/INS-1/PPK/E4/2018 and Research Institute for Natural Material Technology-LIPI for the permission to use SEM-EDX testing equipment in this study.

\section{REFERENCES}

[1]. G. M. Mudd. "Global trends and environmental issues in nickel mining: sulfides versus laterites," Ore Geol. Rev., vol. 38, pp. 9-26, Oct. 2010.

[2]. W. Fu, J. Yang, M. Yang, B. Pang, X. Liu, H. Niu, X. Huang. "Mineralogical and geochemical characteristics of a serpentinite-derived laterite profile from East Sulawesi, Indonesia: implications for the lateritization process and $\mathrm{Ni}$ supergene enrichment in the tropical rainforest," J. Asian Earth Sci., vol. 93, pp. 74-88, Oct. 2014.

[3]. J. Forster, C. A. Pickles, R. Elliot. "Microwave carbothermic reduction roasting of low grade nickeliferous silicate laterite ore," Miner. Eng., vol. 88, pp. 18-27, March. 2016.

[4]. R. Elliott, C. Pickles, J. Peacey. "Ferronickel particle formation during the carbothermic reduction of a limonitic laterite ore," Miner. Eng., vol. 100, pp. 166-176, Jan. 2017.

[5]. Q. Li, Y. Cui, D. Zhu, J. Zhu, J. Pan, H. Zhang, G. Zheng. "Study on selective reduction and magnetic separation of low grade nickel laterite ore to produce high nickel concentrate," in Proc. $X X V$ International Mineral Processing Congress, 2010, pp. 1549-1556.

[6]. R. Elliott, C. A. Pickles and J. Forster. "Pyrometallurgical upgrading of nickeliferous laterites: a comparison of thermodynamic and reduction roasting studies," in Proc. of Nickel Ores and Concentrates'15, 2015.

[7]. R. Elliott, C. A. Pickles and J. Forster. "Thermodynamics of the reduction roasting of nickeliferous laterite ores," Journal of Minerals and Materials Characterization and Engineering, vol. 4, pp. 320-346, Sept. 2016.

[8]. C. T. Harris, J. G. Peacey, and C. A. Pickles, "Selective sulphidation of a nickeliferous lateritic ore," Miner. Eng., vol. 24, pp. 651-660, 2011.

[9]. G-J. Chen, J-S. Shiau, S-H. Liu, and W-S. Hwang. "Optimal combination of calcination and reduction conditions as well as $\mathrm{Na}_{2} \mathrm{SO}_{4}$ additive for carbothermic reduction of limonite ore," Mater. Trans., vol. 57,pp. 1560-1566, 2016.

[10]. M. Rao, G. Li, X. Zhang, J. Luo, Z. Peng, and T. Jiang. "Reductive roasting of nickel laterite ore with sodium sulphate for Fe-Ni production, Part I: reduction/sulfidation characteristics," Sep. Sci. Technol., vol. 51, pp. 1408-1420, 2016

[11]. M. Rao, G. Li, X. Zhang, J. Luo, Z. Peng, and T. Jiang. "Reductive roasting of nickel laterite ore with sodium sulphate for Fe-Ni production, Part II: phase transformation and grain growth," Sep. Sci. Technol., vol. 51, pp. 1727-1735, 2016.

[12]. D. Q. Zhu, Y. Cui, K. Vining, S. Hapugoda, J. Douglas, J. Pan, G. L. Zheng. 'Upgrading low nickel content laterite ores using selective reduction followed by magnetic separation," Int. J. Miner. Process., vol. 106-109, pp. 1-7, May. 2012.

[13]. I. Setiawan, S. Harjanto, A. Rustandi, and R. Subagja. "Reducibility of low nickel lateritic ores with presence of calcium sulfate," International Journal of Engineering and Technology, vol. 14, pp. 56-66, 2014.

[14]. C. T. Harris, J. G. Peacey, and C. A. Pickles, "Selective sulphidation and flotation of nickel from a nickeliferous laterite ore," Miner. Eng., vol. 54, pp. 21-31, 2013.

[15]. M. Jiang, T. Sun, Z. Liu, J. Kou, N. Liu and S. Zhang. "Mechanism of sodium sulfate in promoting selective reduction of nickel laterite ore during reduction roasting process," Int. J. Miner. Process., vol. 123, pp. 32-38, Sept. 2013

[16]. G. Li, T. Shi, M. Rao, T. Jiang, Y. Zhang. "Beneficiation of nickeliferous laterite by reduction roasting in the presence of sodium sulfate," Miner. Eng., vol. 32, pp. 19-26, May. 2012.

[17]. W. Mayangsari \& A. B. Prasetyo. "Proses reduksi selektif bijih nikel limonit menggunakan zat aditif CaSO4," Majalah Metalurgi, 1, 1-68. 2016.

[18]. G. B. Itao, N. M. Anacleto. "Gaseous reduction of laterite ores," Metal Mater. Trans. B, Vol. 2, 26-45, 2011.

[19]. J. Lu, S. Liu, J. Shangguan, W. Du, F. Pan, \& S. Yang. "The effect of sodium sulphate on the hydrogen reduction process of nickel laterite ore," Miner. Eng., 154-164, 2013.

[20]. A. B. Prasetyo, F. Firdiyono, E. Febriana. "Optimasi proses reduksi bijih nikel laterit jenis limonit sebagai bahan baku NPI (Nickel Pig Iron)," Majalah Metalurgi, vol. 29, hal. 9-16. Maret 2014.

[21]. Z. Wang, M. Chu, Z. Liu, H. Wang, W. Zhao, L. Gao. "Preparing ferronickel alloy from low-grade laterite nickel ore based on metallized reductionmagnetic separation," J. Metals, vol. 7, pp. 1-14, August. 2017.

[22]. C. A. Pickles, J. Forster, R. Elliott. "Thermodynamic analysis of the carbothermic reduction roasting of a nickeliferous limonitic laterite ore," Miner. Eng., vol. 65 , pp. 33-40, Oct, 2014. 